\title{
Relationship between Export Promotion Programs and Export Performance: Does Perceived Usefulness Matter?
}

\author{
Osama Mohamed Ahmed Enad, PhD ${ }^{1}$, Abdel Hafiez Ali Hasaballah, PhD², Siddig Balal Ibrahim, PhD $^{3}$, \\ Akram Mohamed Ahmed Alhag, $\mathbf{P h D}^{4}$ \\ ${ }^{1}$ Faculty of Business Administration, Omdurman Islamic University, Khartoum, Sudan
}

${ }^{2}$ Department of Business Administration, College of Business \& Economics, Qassim University, KSA

${ }^{3}$ College of Business Studies, Sudan University of Science and Technology, Khartoum, Sudan

${ }^{4}$ Department of Business Administration, College of Sciences and Arts, Aljouf University, KSA

\begin{abstract}
Several countries have established many export promotion programs to activate their companies' exports product around the world. This study aims to investigate the relationship between the effectiveness of export promotion programs used and export performance in Sudanese export firms; the mediating effect of perceived usefulness, the data have been collected from 68 senior managers of export firm in Sudanese exporting companies. Questionnaire was used to collect the data; overall response rate was $68 \%$. Many statistic tools have been utilized, reliability test, exploratory factor analysis, correlation analysis and hierarchical regression to the goodness of measures and interrelationships. The results showed that export promotion programs significantly influenced the export performance, also perceived usefulness significantly influenced the export performance, beside the significantly relationship between the export promotion programs and perceived usefulness.
\end{abstract}

Keywords: Promotion Programs, perceived usefulness, export performance.

\section{Introduction}

The issue of exporting is an important and ongoing aspect in today's world economy since many countries realized that international trade enhanced the county"s economic growth and development especially in the period of high real productivity exports (Titus, Samuel and Ajao, 2013). Continuing with the issue of exports, countries have many benefits since it gets the division of labor and can produce and reproduce the goods and services that the country benefited them. Moreover, according to Kruger (1 983), investigating the issue of Export Promotion: A Catalyst to Diversification of Productive in Developing Economies found that shifting to an export promotion policy generally results in improved performance in the country"s export earnings.

Therefore, many developing nations are currently shifting to outward-looking policies of export promotion. The strategy has been embraced in order to diversify the economy, generate employment, accelerate economic growth and increase foreign exchange earnings. However, many countries around the world have established public agencies to promote their firms ${ }^{\text {ee }}$ exports and these agencies are endowed with annual budgets ranging from a few hundred thousand dollars to as much as USD 1.3 billion spread over nine agencies in the United States (Jordana et al., 2009; GAO, 2009).

In addition, countries use strategic policies that sustain to promote the nations ${ }^{\text {ee }}$ economic developments, one of these activities include the countryes exports promotion. According to Farrell (2008), Governments may use export promotion in order to accomplish a number of strategic objectives such as the development of a national export culture or as a means of increasing the export competitiveness of a sector of national Importance.

Furthermore, titus et al., (2013) point out that a country involved in exports can also gain from economies of scale and as a result, many of these countries have embarked on various export promotion strategies to tap these and other advantages associated with international exchange. According to Elamin (1997), mentioned Sudan is predominantly an agricultural country with over $90 \%$ of its exports supplied by the agricultural sector. Agriculture is the basic economic activity accounting for more than $35 \%$ of Gross Domestic product (GDP).

Experience has shown that operating abroad involve many difficulties, such as cultural difference, language, laws, and regulations, lack of foreign contacts, and business connections. These factors are ever so difficult for exporters. To be exporter has generally taken along time, and very few have attained a strong position on foreign markets. Despite the effort from the government and some organizations many exporters are couldn't marketing their products perfectly in the foreign market.

Exporting is one of the significant preliminary steps of an enterprising organization towards expanding its international business activities. There is a lack of uniformity in conceptualization, definition and measurement of export performance; and difference among countries' export performance in export literature (Eusebio, et al, 2007). This has contributed to the challenge of identifying and 


\section{International Journal of Science and Research (IJSR) \\ ISSN (Online): 2319-7064}

Index Copernicus Value (2015): 78.96 | Impact Factor (2015): 6.391

understanding the antecedents of export performance. In Sudan there is obvious deteriorating in the exports sector, in last decade Exports were decreasing in 2004 from 677.3 million dollar to 637.0 in 2005 . Actually there are many constrains which have been a difficulty from the effective exporting to the domestic product in the foreign market. What are these constrains? This study focused on the export promotion programs (agreement, foreign trade shows, market studies, online services, deals contact, electronic show and market opportunities) and its effect on the export performance.

\section{Literature Review and Conceptual Framework}

\subsection{Export Promotion Programs}

Governments provide different initiatives of export promotion programs for local firms to help them engage with international business activities. Some of these initiatives include: seminars, market reviews and overseas visits. This is mainly due to helping managers overcome mental barriers and develop positive perception toward exporting operations (False, Nelson Oly, 2009; A.K. Shamsuddoha and M. Yunus Ali).

These export assistance programs are important for increasing firms ${ }^{\text {ee }}$ capabilities/competencies, and for building essential knowledge and experience for successful foreign market involvement (Gencturk and Kotabe, 2001).Further, these characteristics influence (and perhaps are also influenced by) the degree of export involvement of the firm which, in turn, influences export performance.

Understanding the foreign market environment is the first required step for firms wanting to internationalize their operations. However, because of the unfamiliarity of the international business environment and the comparative scarcity of resources, small and medium-sized enterprises (SMEs) are at a disadvantage if they choose to compete internationally)The uncertainties of the exporting, ignorance about foreign markets, and the daunting nature of exporting processes all militate against such firms becoming committed exporters (Seringhaus and Rosson, 1990; Weinrauch and Rao, 1974.

There is no consensus in the literature of how to measure the impact of export promotion. One reason is that export promotion is not a business activity per se, but rather it facilitates firms ${ }^{\text {ee }}$ own activities in a wide variety of ways. The other difficulty is that many factors, of which export promotion programs are only one, influence companies ${ }^{\text {ce }}$ export behavior and performance (June Francis \& Colleen 2004). One line of research has focused on measuring the effectiveness of export promotion programs by two dimensions, perceived adequacy and desired emphasis. Perceived adequacy is measured by many items such as number of services, relative to firm's needs, stimulating export interest, preparation for exporting, export market entry, develop expand export markets, consulting with private sector services. And desired emphasis is calculated by many items such as stimulating export interest, planning preparation for exporting market entry for new exporters, help expand /develop export markets, routine export marketing help for established exporters (F. H. Rolf Seringhaus; Guenther Botschen 2007).

\subsection{Perceived usefulness}

Perceived usefulness is defined as the degree to which people believe using a particular system would enhance their job performance (kai H. Lim 2000). Usefulness refers to the user perception that using this export promotion programs will improve or enhance his or her performance in international business arena. The results of the study indicate that the SMEs that used the export assistance programs have benefited from the programs. There are extensive evidences proving the significance of effect of perceived usefulness on adaptation intention. Perceived usefulness is an important factor in determining adaptation of innovations

\subsection{Export performance}

Exporting is one of the significant preliminary steps of an enterprising organization towards expanding its international business activities. Export performance is the relative success or failure of the efforts of a firm or nation to sell domestically-produced goods and services in other nations. A comprehensive survey of the literature by Katsikeas, et al (2000) revealed that export intensity, export sales, export growth, and export profitability are the four most used measures of economic export performance. Export intensity is the ratio of export sales to a company's total sales and it is the most widely used economic measure of export performance in the literature (Katsikeas et al, 2000). This is followed by export sales, which indicates the size of export earnings in dollar value for a company (Madsen, 1989).

The two other measures of economic export performance are export growth, which is an increase of exports over a certain time period (Aaby and Slater, 1989) and export profitability-either an objective financial measure of profitability of the export venture or a subjective assessment of the profitability of exporting compared to domestic marketing (Baldauf,et,al,2000).

The use of a composite measure of export performance that incorporates financial performance, and managers' subjective assessment of performance of the export market venture has also gained support in recent years (Cavusgil and Zou, 1994; Julian and Ali, 2004; Zou, et al, 1998).

Successful exporting has been described as the engine of economic growth and in the economy has been found to derive their potency in successful exporting. From engaging in export marketing by firms, the number of export marketing studies has continued and is continuing to increase. Over the years, studies in this area have been recognized as a legitimate academic endeavor. (Ezirim, Aloy Chinedu \& Maclayton, 2010).

Katsikeas et al."s (2000) review of the export performance measurement literature identified some categories of performance outcomes: economic measures based on sales, profits and market share; non-economic measures related to export markets (such as number of countries exported to),

\section{Volume 6 Issue 1, January 2017




\section{International Journal of Science and Research (IJSR) \\ ISSN (Online): 2319-7064}

Index Copernicus Value (2015): 78.96 | Impact Factor (2015): 6.391

products and miscellaneous items (including projection of export involvement); and generic subjective measures (including perceived export success, achievement of export objectives, satisfaction with specific export performance indicators and in general).

Measures of impact need to be derived to capture the wide range of export related actions which precede actual sales (Diamantopoulos et al., 1993; Seringhaus, 1986). Ideally, these outcome measures should also closely reflect the scope of export promotion activities (Seringhaus, 1990; Seringhaus and Rosson, 1990). Therefore, we have chosen to use traditional performance outcome measures such as economic performance (export sales in dollars, export intensity, growth in export sales), export diversification (number of countries exported to, percentage of exports to nearest neighbor, i.e. USA), as well as achievement of export objectives, export competencies and export expansion strategies.

\subsection{Conceptual Framework}

There is a lack of uniformity in conceptualization, definition and measurement of export performance; and difference among countries' export performance in export literature (Eusebio, et al, 2007). This has contributed to the challenge of identifying and understanding the antecedents of export performance. A comprehensive survey of the literature by Katsikeas, et al (2000) revealed that export intensity, export sales, export growth, and export profitability are the four most used measures of economic export performance. Export intensity is the ratio of export sales to a company's total sales and it is the most widely used economic measure of export performance in the literature (Katsikeas et al, 2000). This is followed by export sales, which indicates the size of export earnings in dollar value for a company (Madsen, 1989). The theoretical framework is depicted in Figure 1.

\section{Conceptual Framework}

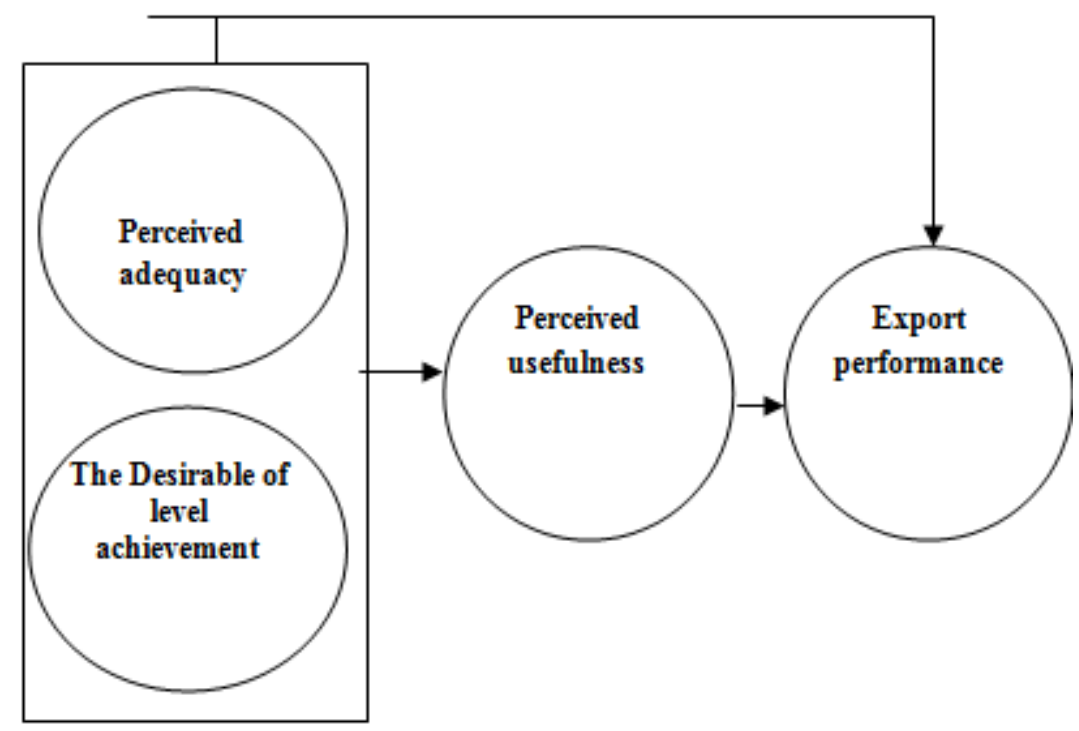

\section{Methodology}

\section{Hypotheses}

Several hypotheses were developed in this study:

H1: There is a positive relationship between programs Adequacy and Export performance.

H2: There is a positive relationship between programs Adequacy and Perceived usefulness.

H3: There is a positive relationship between Perceived usefulness and Export performance.

H4: Perceived usefulness mediates the relationship between programs Adequacy and Export performance

\section{Methodology}

This paper tries to investigate the impact of promotion programs on export performance; the role of perceived usefulness as mediator between the independent and dependent variable; data were collect from export Sudanese agricultural and animal firms. For the purpose of generating information about Sudanese agricultural and animal companies exporting to the world, the directory gained from the ministry of Sudanese trade foreign representatives in Union of Champers Commerce (UCC); The UCC 2012 has 800 export companies. A total of 100 questionnaires were distributed to the respondents. A total of 68 questionnaires the overall response rate was $68 \%$.

The questionnaire consisted of two sections. The first section gathered the demographic profile such as gender, age, level of study, and marital status, whereas the second section was about the main focus of this study and gathered export firms directors ${ }^{\text {ee }}$ respondents regarding the four main variables namely, programs perceived adequacy, desired emphasis, Perceived usefulness and Export performance. The data collected was keyed-in the Statistical Package for Social sciences (SPSS) version 17.0. Both descriptive and inferential statistics were reported. Bivariate correlation and linear multiple regression were used to test the hypothesized model.

\section{Volume 6 Issue 1, January 2017 www.ijsr.net}




\section{International Journal of Science and Research (IJSR) ISSN (Online): 2319-7064}

Index Copernicus Value (2015): 78.96 | Impact Factor (2015): 6.391

\section{Data Analysis}

To ensure the goodness of measurement exploratory factor analysis (principal component analysis) was conducted on export promotion programs, perceived usefulness and export performance. Further, Reliability test (Cronbach's alpha) was done to measure the internal consistency of the items used on the questionnaire. These two methods were very important to assess the goodness of the measures (Sekaran 2003). Demographic analysis was done to understand the characteristics of the respondents, Correlation test was conducted to measure the relationship among the variable, and regression analysis was also conducted in the study in order to test the relevance of the hypotheses.

\subsection{Demographics}

The table 4.2 shows that respondents who work in agricultural production firms were $(66.7 \%)$ as a highest ratio. Followed by animals production firms respondents $(22.2 \%)$ and other firms were $(11.1 \%)$, respectively as lowest ratio. The table 4.2 also shows the respondents jobs, managers represented $(60.3 \%)$ as a highest ratio, employees (19.1\%) and lastly, the other jobs was (6.9\%) as lowest ratio. Regarding the respondents ages between (20 to 29) year was account $(19.1 \%)$ whereas the respondent's ages between (30 to 39$)$ years were $(32.4 \%)$ as a highest ratio, and those whom between (40 to 49 ) have recorded $(20.6 \%)$ and lastly the respondent"s ages above 50 year recorded (20.6\%).

Also to Concentrating on the respondents ${ }^{\text {ee }}$ gender, most of them were males $(92.6 \%)$ and the other hand female reported $(4.4 \%)$. Beside, the level of education for respondents whom fill up the questionnaires, majority of them were graduate, account (55.9\%) followed by secondary school $(26.5 \%)$ and the postgraduate $(17.6 \%)$ as lowest ratio. About the respondents experience, the table shows that; the respondents whom have worked in the firms from (15 years and more) have accounted (27.9\%) equally with respondents from (5 to 10 years) followed by whom have worked from (11 to 15 years ) have recorded $(22.1 \%)$ and those respondents whom were ( less than 5 years) have accounted $(20.6 \%)$ as lowest ratio.

Regarding to the number of employees in the firm, the table shows that firms (less than 10 employees) were account (32.4\%) as highest ratio. And the firms from (11 less than 25 employees) have accounted (30.9\%) followed by firms from (26 to 50 employees) have accounted (19.1\%) and lastly, the firms (above than 50 employees) were account (17.6\%) as lowest ratio. To concentrating on the respondents involvement, active exporters were $(58.8 \%)$ as a highest ratio, followed by sporadic exporters have recorded (19.4\%) and lastly pre-exporters have accounted (10.3\%) as lowest ratio. Finally, concerning on export promotion programs, trade agreement recorded $(75 \%)$ as a highest ratio, followed by market studies $(66 \%)$ and followed by export development accounted (63\%) and foreign trade show has reported $(57.4 \%)$ equally with online service. Also export market opportunities has recorded $(48.5 \%)$ followed by electronic shows $(45.6 \%)$ as the lowest ratio.
Table 1: Demographic Characteristics

\begin{tabular}{|c|c|c|c|}
\hline Variables & Categories & frequency & Percent \\
\hline \multirow[t]{6}{*}{$\begin{array}{c}\text { Type of export } \\
\text { Job }\end{array}$} & $\begin{array}{c}\text { Agricultural } \\
\text { production firms }\end{array}$ & 42 & 66.7 \\
\hline & $\begin{array}{l}\text { Animal production } \\
\text { firms }\end{array}$ & 14 & 22.2 \\
\hline & Others firms & 7 & 11.1 \\
\hline & Manager & 41 & 60.3 \\
\hline & Employee & 13 & 19.1 \\
\hline & Other & 4 & 6.9 \\
\hline \multirow[t]{4}{*}{ Age } & From 20 to 29 & 13 & 19.1 \\
\hline & 30 less than 39 & 22 & 32.4 \\
\hline & 40 less than 49 & 19 & 20.6 \\
\hline & More than 50 & 14 & 20.6 \\
\hline \multirow[t]{2}{*}{ Gender } & Male & 63 & 92.6 \\
\hline & Female & 3 & 4.4 \\
\hline \multirow[t]{3}{*}{ Education level } & Secondary & 18 & 26.5 \\
\hline & bachelor & 38 & 55.9 \\
\hline & postgraduate & 12 & 17.6 \\
\hline \multirow{4}{*}{$\begin{array}{l}\text { Worke"s } \\
\text { experience }\end{array}$} & Less than 5 years & 14 & 20.6 \\
\hline & 5 less than 10 & 19 & 27.9 \\
\hline & 11 less than 15 & 15 & 22.1 \\
\hline & 15 and more & 19 & 27.9 \\
\hline \multirow{5}{*}{$\begin{array}{l}\text { Number of } \\
\text { employees }\end{array}$} & Less than 10 & 22 & 32.4 \\
\hline & 11 less than 25 & 21 & 30.9 \\
\hline & 26 less than 50 & 13 & 19.1 \\
\hline & 50 and above & 12 & 17.6 \\
\hline & Continuing export & 40 & 58.8 \\
\hline \multirow{2}{*}{$\begin{array}{c}\text { Export } \\
\text { involvement }\end{array}$} & Sporadic export & 20 & 29.4 \\
\hline & Pre-exporters & 7 & 10.3 \\
\hline \multirow[t]{2}{*}{ trade agreement } & Yes & 51 & 75 \\
\hline & No & 17 & 25 \\
\hline \multirow{2}{*}{$\begin{array}{l}\text { foreign trade } \\
\text { show }\end{array}$} & Yes & 39 & 57.4 \\
\hline & No & 29 & 42.6 \\
\hline \multirow[t]{2}{*}{\begin{tabular}{|l|} 
market studies \\
\end{tabular}} & Yes & 45 & 66.2 \\
\hline & No & 23 & 33.8 \\
\hline \multirow[t]{2}{*}{ online service } & Yes & 39 & 57.4 \\
\hline & No & 29 & 42.6 \\
\hline \multirow{2}{*}{$\begin{array}{l}\text { Electronic } \\
\text { show }\end{array}$} & Yes & 31 & 45.6 \\
\hline & No & 37 & 54.4 \\
\hline \multirow{2}{*}{$\begin{array}{c}\text { export } \\
\text { development }\end{array}$} & Yes & 43 & 63.2 \\
\hline & No & 25 & 36.8 \\
\hline \multirow{2}{*}{$\begin{array}{c}\text { E market } \\
\text { opportunities }\end{array}$} & Yes & 33 & 48.5 \\
\hline & No & 35 & 51.5 \\
\hline
\end{tabular}

\subsection{Factor Analysis}

\section{A. Factor analysis on programs adequacy}

Exploratory factor analysis was conducted for the programs adequacy construct, using principle component analysis with Varimax rotation. All items involved in the process and there were no items deleted. Before interpreting the factor loadings, appropriateness for running factor analysis was conducted using Kaiser-Meyer-Olkin (KM)) and Bartlttes test of sphericity. A higher score for KMO (>.50) with significant Bartltt's test of sphericity indicates that the data is suitable for conducting factor analysis. The KMO for this construct was .897 which is higher than the required point, while the Bartltt's test of sphericity was significant at .05 level. All items loaded into a single construct with a total variance explained of $65.2 \%$. Factor loadings were higher than .60 , ranging from .680 to .847 . The highest loading belong to the seventh item (These programs contribute to expand the export market) with .847 whereas the lowest 


\section{International Journal of Science and Research (IJSR) \\ ISSN (Online): 2319-7064 \\ Index Copernicus Value (2015): 78.96 | Impact Factor (2015): 6.391}

loading accounted for last item (These programs fulfill the desires about the export planning) with a loading of .680 .

Table 2: Rotated factor for programs adequacy

\begin{tabular}{|c|c|c|}
\hline $\begin{array}{c}\text { Items } \\
\text { No: }\end{array}$ & Programs adequacy. & Component \\
\hline PA7 & $\begin{array}{c}\text { These programs contribute to expand the } \\
\text { export market }\end{array}$ & 0.847 \\
\hline PA6 & $\begin{array}{c}\text { These programs achieving the exporters } \\
\text { desired in the export market }\end{array}$ & 0.821 \\
\hline PA9 & $\begin{array}{c}\text { These programs contribute to achieving the } \\
\text { desirable interest }\end{array}$ & 0.819 \\
\hline PA3 & $\begin{array}{c}\text { These programs adequate to the export } \\
\text { activities }\end{array}$ & 0.817 \\
\hline PA 4 & $\begin{array}{c}\text { These programs helping the entering the } \\
\text { export market }\end{array}$ & 0.808 \\
\hline PA5 & $\begin{array}{c}\text { These programs helping the developing the } \\
\text { export market }\end{array}$ & 0.796 \\
\hline PA2 & $\begin{array}{c}\text { These programs meeting the firms need in the } \\
\text { export market }\end{array}$ & 0.783 \\
\hline PA1 & $\begin{array}{c}\text { The programs helping for activate export } \\
\text { market }\end{array}$ & 0.765 \\
\hline PA8 & $\begin{array}{c}\text { These programs fulfill the desires about the } \\
\text { export planning (deleted) }\end{array}$ & 0.68 \\
\hline Total variance explained & 65.211 \\
\hline Kaiser-meyer-olkin(KMO) & 0.897 \\
\hline Bartltt"'s test of Spherecity & 280.8 \\
\hline
\end{tabular}

Variable loaded significantly on factor with coefficient of at least $0.05, *$ items deleted due to high cross loading.

\section{B. Factor analysis on perceived usefulness}

A similar procedure was conducted on the second construct: perceived usefulness. Before going further interpretation, a suitability of running factor analysis was conducted and found very suitable. Five items were included in the process and all of them loading into a single component. The total variance explained by these items was $65 \%$ with is above the recommended cut-point. The factor loadings ranged from .654 to .835 . The higher loading was found to belong to item PU3 (using promotion programs would be more useful) with .835. The second item (PU2) obtained the lowest loading of .654. However, these loadings are higher than the recommendations of the literature (Hair et al., 2010) which is .50 and above.

Table 3: Rotated factor for perceived usefulness

\begin{tabular}{|c|c|c|}
\hline $\begin{array}{c}\text { Items } \\
\text { No: }\end{array}$ & Perceived usefulness & Component \\
\hline PU3 & using promotion programs would be more useful & $\mathbf{0 . 8 3 5}$ \\
\hline PU1 & $\begin{array}{c}\text { using promotion programs would be more } \\
\text { effectiveness }\end{array}$ & $\mathbf{0 . 8 1 6}$ \\
\hline PU 5 & $\begin{array}{c}\text { using promotion programs would be more } \\
\text { productivities }\end{array}$ & $\mathbf{0 . 8 1 3}$ \\
\hline PU4 & using promotion programs would be more quickly & $\mathbf{0 . 7 4 7}$ \\
\hline PU2 & $\begin{array}{c}\text { using promotion programs would be more } \\
\text { performance (deleted) }\end{array}$ & $\mathbf{0 . 6 5 4}$ \\
\hline \multicolumn{2}{|c|}{ Total variance explained } & 64.551 \\
\hline \multicolumn{2}{|c|}{ Kaiser-meyer-olkin(KMO) } & 0.714 \\
\hline \multicolumn{2}{|c|}{ Bartltte's test of Spherecity } \\
\hline
\end{tabular}

Variable loaded significantly on factor with coefficient of at least $0.05, *$ items deleted due to high cross loading.

\section{Factor analysis on export performance}

The last construct conducted for the factor analysis was export performance. This construct consisted of five items and all of them loaded, as expected, into a single component. The factor loadings were very high compared to other constructs and ranged from .791 to .890 . The lowest loading (.791) obtained by the last item (These programs contribute to achieving the objectives of the firms whereby the first item (EX1: These programs contribute to increase the sales of export product) scored the highest factor loading (.890). The five items of export performance accounted for $70 \%$ of variance explained which is above the recommended values.

Table 4: Rotated factor for export performance

\begin{tabular}{|c|l|r|}
\hline $\begin{array}{c}\text { Items } \\
\text { No: }\end{array}$ & \multicolumn{1}{|c|}{ Export performance } & Component \\
EX1 & $\begin{array}{l}\text { These programs contribute to increase } \\
\text { the sales of export product }\end{array}$ & $\mathbf{0 . 8 9}$ \\
\hline EX2 & $\begin{array}{l}\text { These programs contribute to improve } \\
\text { the profitability the export product }\end{array}$ & $\mathbf{0 . 8 6 6}$ \\
\hline EX4 & $\begin{array}{l}\text { These programs contribute to improve } \\
\text { the overall financial performance in the } \\
\text { export market }\end{array}$ & $\mathbf{0 . 8 3 3}$ \\
\hline EX3 & $\begin{array}{l}\text { These programs contribute to improve } \\
\text { the market share for the exports in the } \\
\text { export market }\end{array}$ & $\mathbf{0 . 8 0 5}$ \\
\hline EX5 & $\begin{array}{l}\text { These programs contribute to achieving } \\
\text { the objectives of the firms }\end{array}$ & $\mathbf{0 . 7 9 1}$ \\
\hline \multicolumn{2}{|c|}{ Total variance explained } & 70.184 \\
\hline \multicolumn{2}{|c|}{ Kaiser-meyer-olkin(KMO) } & 0.883 \\
\hline \multicolumn{2}{|c}{ Bartlttc's test of Spherecity } \\
\hline
\end{tabular}

Variable loaded significantly on factor with coefficient of at least $0.05, *$ items deleted due to high cross loading.

\subsection{Reliability test}

To test the reliability of the study Cronbach ${ }^{\text {ee }}$ Alpha was used to measure the internal consistency of the variables; according to Cronbach's Alpha the variable must score 0.7 to be internal consistency (hair et al, 2010). The table below shows that all variables have Cronbach Alpha values of more than 0.7.which makes all variables accepted, internally consistent and the scale deemed reliable for further analysis.

Table 5: Cronbachs alpha for study variables

\begin{tabular}{|l|c|c|}
\hline \multicolumn{1}{|c|}{ Variables } & Number of items & Crombach ${ }^{\text {ec }}$ alpha \\
\hline Programs Adequacy & 8 & .930 \\
\hline Perceived usefulness & 4 & .809 \\
\hline Export performance & 5 & .894 \\
\hline
\end{tabular}

\subsection{Correlation of variables}

Table 6 above shows the result of the inter correlations among the variables. The tables indicated that the mean value for both variables is above average, indicating that they are positively and sufficiently correlated with each other. The table shows that programs Adequacy is positively and significantly correlated with perceived usefulness ( $\mathrm{r}$ $=.466, \mathrm{p}$-value $<0.01$ ). Programs Adequacy is positively and significantly correlated with Export performance $(r=.625, p-$ value $<0.01)$ and perceived usefulness is positively and significantly correlated with Export performance $(r=.393$, $p$ value <0.01); Therefore, both independents and the 


\section{International Journal of Science and Research (IJSR) \\ ISSN (Online): 2319-7064}

Index Copernicus Value (2015): 78.96 | Impact Factor (2015): 6.391

dependents variable of this study are sufficiently correlated and no multicolinearity detected.

Table 6: Correlation between variables

\begin{tabular}{|c|c|c|c|c|c|}
\hline Variables & Mean & $\begin{array}{c}\text { Standard } \\
\text { Deviation }\end{array}$ & $P A$ & $P U$ & $E P$ \\
\hline $\begin{array}{c}\text { Programs } \\
\text { Adequacy PA }\end{array}$ & 3.57 & 0.952 & 1 & & \\
\hline $\begin{array}{c}\text { Perceived } \\
\text { usefulness PU }\end{array}$ & 4.02 & 0.767 & $.466^{* *}$ & 1 & \\
\hline $\begin{array}{c}\text { Export } \\
\text { performance EP }\end{array}$ & 3.44 & 1.062 & $.625^{* *}$ & $.393^{* *}$ & 1 \\
\hline
\end{tabular}

\subsection{Hypothesis Test}

The table 7 below shows the result from hierarchical regression between programs adequacy and export performance. The programs adequacy variable cumulatively contributed $39 \%$ of the variance in export performance; the table further shows positive and significant relationship between the variables $(\beta=0.625 ; \mathrm{F}$ change $=37.225)$, hence H1 (between programs adequacy and export performance) were accepted.

Table 7: Multiple Regressions: programs adequacy and export performance

\begin{tabular}{|l|l|}
\hline Variable & Export performance \\
\hline Programs adequacy & $.625^{* *}$ \\
\hline$R^{2}$ & .391 \\
Adjusted $R^{2}$ & .380 \\
$\triangle R^{2}$ & .391 \\
F change & $37.225^{* *}$ \\
\hline
\end{tabular}

Note: level of significant: ${ }^{*}<0.10,{ }^{*} \mathrm{p}<0.05,{ }^{* * *} \mathrm{p}<$.

The second hypothesis of the study indicated that there is a positive relationship between programs Adequacy and Perceived usefulness. The result shows (table 8) that the programs adequacy is a positive significantly influencedperceived usefulness $(\beta=0.466 ; \mathrm{F}$ change $=$ $16.679)$; the program adequacy explain $21 \%$ of the variance on Perceived usefulness then hypothesis (H2) fully accepted.

Table 8: Multiple regressions: programs adequacy and perceived usefulness

\begin{tabular}{|c|c|}
\hline Variable & Perceived Usefulness \\
\hline programs adequacy & $.466^{* 8}$ \\
\hline $\begin{array}{l}\mathrm{R}^{2} \\
\text { Adjusted } \mathrm{R}^{2} \\
\triangle \mathrm{R}^{2} \\
\mathrm{~F} \text { change }\end{array}$ & $\begin{array}{l}.218 \\
.204 \\
.218 \\
16.679 * * *\end{array}$ \\
\hline
\end{tabular}

Note: level of significant: $* \mathrm{p}<0.10,{ }^{* *}$

Also the study investigated that there is a positive relationship between Perceived usefulness and Export performance. The result on below table (9) shows that perceived usefulness is a positive significantly influenced export performance $(\beta=0.393 ; F$ change $=10.442)$; hypothesis three fully supported, However the independent variable explain $15 \%$ of the variance on export performance.
Table 9: Multiple regression: perceived usefulness and export performance

\begin{tabular}{|l|l|}
\hline Variable & Export performance \\
\hline Perceived usefulness & $.393^{* *}$ \\
\hline $\mathrm{R}^{2}$ & .155 \\
Adjusted $\mathrm{R}^{2}$ & .140 \\
$\triangle \mathrm{R}^{2}$ & .155 \\
$\mathrm{~F}$ change & $10.442^{* * *}$ \\
\hline
\end{tabular}

Note: level of significant: ${ }^{*} \mathrm{p}<0.10,{ }^{* *} \mathrm{p}<0.05$

To test the effect perceived usefulness as mediator of the Relationship between programs adequacy and export performance; this study was applied a three-step hierarchical regression recommended by Baron and Kenny (1986). Table (10) below shows the result of hierarchical regression testing the mediation effect of perceived usefulness onthe Relationship between programs adequacy and export performance.

In model 1, the result showed that programs adequacy significantly influence export performance $(B=.672)$ and Perceived usefulness $(\mathrm{B}=0.632)$ in model 2 , As the result showed in table (10); that perceived usefulness partially mediate the Relationship between programs adequacy and export performance .

Table 10: Mediating effect of programs adequacy and export performance

\begin{tabular}{|l|l|c|}
\hline Variable & Model 1 & Model 2 \\
\hline Promotion adequacy & $.672^{* *}$ & $.632^{* *}$ \\
\hline $\mathrm{R}^{2}$ & .425 & .457 \\
Adjusted $\mathrm{R}^{2}$ & .442 & .438 \\
$\triangle \mathrm{R}^{2}$ & .452 & .005 \\
$\mathrm{~F}$ change & $47.027^{* * *}$ & .527 \\
\hline
\end{tabular}

Note: level of significant: $* \mathrm{p}<0.10,{ }^{*} \mathrm{p}<0.05$

\section{Findings and Discussion}

The relationship between programs adequacy and export performance, the results of this study show that programs adequacy have positive relationship with export performance; hypothesis one fully supported. This finding is consistent with the up to dated research done by June Francis, Colleen Collins-Dodd (2003) which reported that the effectiveness of export assistance programs is improving the competence of firms, helping them to achieve their export objectives and export performance.

This result is also similar to previous studies by (Czinkota, 1996; Diamantopoulos et al., 1993; Seringhaus and Rosson, 1990). Samiee and Walters (1991), Kotabe and Czinkota (1992) and Moini (1998) had also reported a positive relationship between effectiveness of government export assistance programs across types of exporters and export performance. This outcome is also agrees with (F. H. Rolf Seringhaus; Guenther Botschen 2007) which argues that Export promotion programs is widely used contributing to support exporting performance of private sector firm. also the result of this study similar to (A.K. Shamsuddoha ) which argued that managerse extent of usage of export promotion programs positively influence managers ee export knowledge and their positive perception toward export market environment that consequently influence export 


\section{International Journal of Science and Research (IJSR) \\ ISSN (Online): 2319-7064}

Index Copernicus Value (2015): 78.96 | Impact Factor (2015): 6.391

strategy and ultimately export performance. also the result of this study similar to (Christian volpe martincus, jerónimo carballo 2007) which reported that export promotion activities helped firms to expand their exports, essentially along the extensive margin, both in terms of markets and products.

We also found that existence of positive Relationship between export programs adequacy and perceived usefulness. The exporters believed that if there is a perceived benefit from these programs, it will contribute to increase the number of programs; (H2) was supported. This finding is consistent with the previous research done by Marandu (1995); he argued that the perceived benefit from the programs leads to better performs in the export market.

The study found that there is positive relationship between perceived usefulness and export performance (H3) was fully supported. The finding means that the perceived usefulness from these programs will enhance the economic performance (increase the sales, profitability, market share,) and improve the non-economic performance; but the firms need to increase the number of programs used (the firms focused on three programs just) for that their performance were low down in the export market on the ground. With regard to this, the five agencies need to increase the SMEs ${ }^{\text {ee }}$ commitments using the various export assistance programs offered by them. These agencies can do so by showing the potential tangible benefits a firm can gain from using the various export assistance programs. the result linked with (Cavusgil and Michael, 1990; Marandu, 1995; Seringhaus and Rosson, 1990) which argues that success of Government export promotion programs play a key role in stimulating international business activities of firms.

Finally the study investigated the Mediating Impact of perceived usefulness on the Relationship between programs adequacy and export performance. Mediation variable is the one that emerges between the time the independent variables operate to influence the dependent variable. It surfaces as the function of the independent variable and helps to explain the influence of the independent variable on the dependent variables (Sekaran, 2000). Most of previous studied have used the usage and usefulness together, the current study separated between them and utilized the perceived usefulness as a mediator. Nevertheless, there are many studies used the perceived usefulness in different sector as a mediator such as (Ann L. Fruhling and Eleanor T. Loiacono 2009) beside ( Yogesh Malhotra and Dennis F. Galletta) in support of usefulness can be use in the export sector as a mediator.

\section{Suggestions for Future Studies}

This research represents an early attempt to build and test a theoretical framework promotion programs. However, relied on the limitations of the study which have mentioned above, this research provides some suggestions for future research. These suggestions have detailed in the following: future studies can replicate this study using larger sample and dissimilar contexts such as different sectors or dissimilar countries. Beside, the theoretical framework of this study was limited, for further studies can enter some variables such as moderating variables or it can increase the elements of the variables.

\section{References}

[1] A.K. Shamsuddoha and M. Yunus Ali, Direct and Indirect Impact of Export Promotion Programs on Export Performance, Queensland University of Technology pp 2-6

[2] Christian volpe martincus \& jerónimo carballo, (2007), is export promotion effective in developing countries? Firm-level evidence on the intensive and extensive marginsof exports, Annual Conference of the European Trade Study Group Athens, September 15, 2007,pp312.

[3] Elamin, N. A. (1997). Export Performance in Sudan: Recent Trends and Policy Impact. Journal of Econoomic Cooperation Among Islamic Countries, 18 (4), 57-76.

[4] F. H. Rolf Seringhaus; Guenther Botschen, (1991), Cross-National Comparison of Export Promotion Services: The Views of Canadian and Austrian Companies, Journal of International Business Studies, Vol. 22, No. 1, pp 115-133.

[5] FalseAndrew Parker \& David Wighton, (1998), ,, Case for independent export promotion has yet to be sold to the Foreign Office ${ }^{\text {exe; }}$ Government support for companies seeking business abroad is expected to be rebranded, Financial Times, United Kingdom, p22.

[6] False Ackerman, Karen Z, (1993), ,„Export promotion programs help U.S. products compete in world markets ${ }^{\text {eee }}$ Food Review, pp 66-79.

[7] Farrell, C. (2008). The Role of the Internet in the Delivery of Export Promotion Services: A Web Site Content Analysis. JOURNAL OF GLOBAL MARKETING, 21 (4), 259-270.

[8] General Accounting Office. 2009. "Observations on U.S. and Foreign Countries ${ }^{\text {ee }}$ Export Promotion Activities: Statement of Loren Yager, Director International Affairs and Trade", GAO report number GAO-10-310T, December 9, 2009.

[9] Hair J. F., Anderson R.E., Tatham R. L., and Black W. C. (1998). Multivariate Data Analysis. Prentice-Hall International, Inc, USA.

[10]Hair, J.F., Anderson, R.E., Tatham, R.L. \& Black, W.C. (2010), Multivariate Data Analysis (7th ed.), Prentice Hall Inc Upper Saddle River, NJ

[11]Ihsan A. market- oriented strategic planning for Sudanese live sheep and sheep meat export business in Saudi Arabia markets, Khartoum university magazine, and p56.

[12] June Francis \& Colleen Collins Dodd, (2004), ,„,mpact of export promotion programs on firm competencies eere strategies and performance, the case of Canadian hightechnology SMEs", International Marketing Review, Vol. 21 Iss: 4 PP 474-492

[13] John W. Mullins, Orville C. Walker JR. Harper W. Boyd JR (2008), ,Marketing management: strategic decision marketing approach ${ }^{\text {eeee }}$ pp 332-437.

[14] Jameel Ahmed Khader, (2002), „International marketing management ${ }^{\text {eee }}$ Oman Jordan, Applied silence university. 


\section{International Journal of Science and Research (IJSR) \\ ISSN (Online): 2319-7064 \\ Index Copernicus Value (2015): 78.96 | Impact Factor (2015): 6.391}

[15]J.Denis Belisle (2000), „,International trade centre: executive forum redefining trade promotion the need for a strategic response eere pp 20-43.

[16] Jordana Casajuna, Jacint, Christian Volpe Martincus and Andrés Gallo. 2009. "Latin American and Caribbean export promotion agencies: An institutional characterization," IDB, forthcoming.

[17] Jordana Casajuna, Jacint, Christian Volpe Martincus and Andrés Gallo. 2009. "Latin American and Caribbean export promotion agencies: An institutional characterization," IDB, forthcoming.

[18]Kumar, K., Subramanian, R. and Strandholm, K. (2001). Competitive strategy, environmental scanning and performance: a context specific analysis of their relationship, International Journal of Commerce and Management, Vol. 11 No. 1, pp. 1-33.

[19] Kruger, A. (1983): "Export Promotion: A Catalyst to Diversification of Productive in Developing Economies". Department of Trade and Industry, South Africa

[20] Malhotra, A., Gosain, S. and El Sawy, O.A. (2005). Absorptive capacity configuration in supply chains: gearing for partner-enabled market knowledge creation, MIS Quarterly, Vol. 29 No. 1, pp. 145-87.

[21] Nunnally, J.C. \& Bernstein, I.H. (1994). Psychometric Theory, New York, McGraw-Hill

[22] Nunnally, J.L. (1978). Psychometric Theory, 2nd ed., McGraw-Hill, New York, NY

[23] Nadim J.\& Noorjahan B. (2008) The role of perceived usefulness, perceived ease of use, security and privacy, and customer attitude to engender customer adaptation in the context of electronic banking, African Journal of Business Management Vol.2, pp. 32-40.

[24] Nasredin A. Hag Elamin, (1997), export performance in Sudan,Journal of economicCooperation among Islamic countries, pp 57- 76.

[25] Orville, C. Walker, Jr. John W. Mullins, Harper W. Boyd, Jr. Jean elaude larreche (2006), ,Marketing strategy a decision focused approach ${ }^{\text {eeee }}$. American, New York. Pp. 316-322.

[26] Roberto alvarez e.\& gustavo crespi t,(2000) exporter performance and promotion Instruments: chilean empirical evidence, exstpuodritoesr dpee refocromnoanmcíea, .a vol 27-no 2, pp 2-10

[27] Sekaran, U. (2003). Research Methods for Business: A Skill Building Approach.Singapore: John Wiley\& Sons, Inc.

[28] Sharma, A. (2006). Strategies for maximizing customer equity of low lifetime value customers. Journal of Relationship Marketing, Vol. 5(1), pp. 59-77.

[29] Sharma, J. Aragon-Correa, A.J \& Rueda-Manzanares, A. (2007). The contingent influence of organizational capabilities on proactive environmental strategy in the service sector: an analysis of North American and European Ski Resorts. Canadian Journal of Administrative Sciences, 24, 268-283.

[30] Sharma, S. (2000), "Managerial interpretation and organizational context as predictors of corporate choice of environmental strategy", The Academy of Management Journal, Vol. 43 No. 4, pp. 681-97.

[31] Sharma, S. and Henriques, I. (2005), "Stakeholder influences on sustainability practices in the Canadian forest services industry", Strategic Management Journal, Vol. 26, pp. 159-80.

[32] Sharma, S., Durand, M.R. \& Gur-Arie, O. (1981). Identification and analysis of moderator variables. Journal of Marketing Research, 18(3), 291-300.

[33] Sohail M. Sadiq Alashban \& Aref , (2009), „,An analysis of product-market strategy and export performance,International Journal of Entrepreneurship ${ }^{\text {eece }}$.

[34] Tabachnick, B. G., \& Fidell, L. S. (2001). Using Multivariate Statistics (4th ed.). Needham Heights, MA: Allyn \& Bacon.

[35]T. Ramayah \& Joshua Ignatius. Impact of Perceived usefulness, Perceived ease of use and Perceived Enjoyment Intention to shop online, Universiti Sains Malaysia ,pp 4-12, victoria champion, perceived benefits, Indiana university 2 .

[36] Titus, O. A., Samuel, D. O., \& Ajao, O. S. (2013). A Comparative Analysis of Export Promotion Strategies In Selected African Countries (South Africa, Nigeria and Egypt). International Journal of Management Sciences, 1 (6), 204-211.

[37] William D.Perreault, Jr.E.Jerome, Basic Marketing- A Global-managerial approach, pp380-400

Volume 6 Issue 1, January 2017

www.ijsr.net 